\title{
A Metaphysics for a Neo-Modernity- Beyond the Feminine and the Masculine: The Humanity ${ }^{1}$
}

\author{
Alfredo de Oliveira Moraes
}

Professor, Department of Philosophy and Member of the Research Ethics Committee Involving Human Beings of the Federal University of Pernambuco-UFPE, Brazil

\begin{abstract}
The author desire to present a contribution to think the actual reality, such it is feasible to apprehend it come from the scientific knowledge at present time; for the author it is not enough to do a critical on aspects or specific points of that reality, but is an urgent problem to re-think the thought that produced that reality; so, it is not enough criticize the effects but the cause. In this way for a critical on the woman situation in the actual context it is necessary, at first, to construct concepts, categories and elements of philosophical thought that meet the specificities of feminine thinking. So, for a critical on that reality we have to face the basis of the thought that produced it, this basis is found in the Metaphysic, thence is indispensable to comprehend the Metaphysic from its begin, what the reason for its creation, its delimitation and, as well, the failure of the critical to the metaphysical thought. At long last, the author advocates the thesis that only changing de metaphysical basis, we will have the possibility to change the apprehension of the reality to put a new reality for a Neo-Modernity.
\end{abstract}

Keywords - Metaphysic, Substance, Relational basis.

\footnotetext{
${ }^{1}$ English version by Vinícius Cavalcanti Lima de Moraes from my article (here enlarged and modified) published by the Kalagatos, Fortaleza, Vol.15, N.1, 2018, p. 203-217. - Uma metafísica para além do feminino e do masculino.
}

At first, I begin by the question that will guide, subliminally, my thought in the development this text. I had observe that in history and in the present reality, many women have raised respect dignity, bravery, intelligence and human thought without engaging in the defense of feminism; on the other hand, an immense multitude suffered and still suffers only for being women. And in Philosophy, the science that the foundation and the unveiling of every human action and construct, what about the presence of the woman?

I do not want here to make a historical or historiographic account of the female philosophy, I leave this task to others, but I want to put in debate the possibility of construction of concepts, categories and elements of philosophical thought that meet the specificities of feminine thinking. I am not happy to think, abstractly, in empty universals, I am by profession attached to actual reality, to the unique or universal, nor do I intend to contribute to a reasoning which, limited to understanding, is only able to separate and distinguish, unable to grasp the unity the multiplicity of the differences that integrate it. Nor, I am of the anti-dialectics who only think or this or that, I am rather among those who think the contradiction, not to solve it or to extinguish it, but in the perspective that everything that exists, simply by existing, is contradictory in itself $\mathrm{I}$ do not need to eliminate or exalt the contradiction, it's there, what we cannot make it an injustice, a reason for prejudice or even worse understand life as a struggle because there are contradictions in it.

Therefore, I defend that to think the whole is necessary to think the parts that therefore, as we have the categories, elements and concepts from the masculine determination of humanity, it is equally essential that we have the categories, the elements and concepts thought from the feminine determination of humanity, so that we can properly apprehend humanity and your world. In fact, I believe that we have a common substrate that we share in the background of our belief system which I identify as present in human cultures under various names and which, among us, is presented in the Metaphysical foundation in which all our knowledge is rooted and settled. Moreover, material-based Metaphysics adopted in the philosophical tradition and still today as if it were the only possible one is the last, primordial and essential foundation for all thinking in Politics, Economy, Science, Theology, Philosophy, Art, social and personal relations, in short, in 
everything that is human in contemporaneity; which is why the most urgent task is to call into question this materialbased metaphysics.

I present a proposal to rethink the foundations of Metaphysics, taking as Hegelian thought of a metaphysics of spiritual base, based on the substance that is subject ("Die lebendige Substanz ist ferner das Sein, welches in Wahrheit Subjekt"2), to propose a metaphysics of nonmaterial basis, whose foundation is based on the dynamic totality of self-centered relations that constitutes the subject substance.

It has already been said that Philosophy is an act of daring, whether moved by 'admiration' in the face of the universe whether in its macro, micro or nano dimension - or by passion, in Hegelian sense, of being something to which the person gives himself in its entirety and with exclusivity to the object of his desire. I dare, and I am aware that this puts me against the thought that still dominates the philosophical scene, and invisibly supports sciences, the economic system that gives it feedback, and the political decisions that justify it, as well as ideologies.

My essential point is that to Metaphysics it is not enough to deviate from an alleged 'deviation', or to resign itself to an announced end, while a depletion of its possibilities of existing, let alone accepting the emptying of the meaning of its $\log$ os - as the reason for discourse and discourse of reason; Metaphysics does not, as well, have the bias of a criticism that without being able to illuminate its foundations if in an emissivity of an umbilical monologue that despises the actual contributions of the particular contemporary sciences, moreover, of those on which the academy is still reluctant to cope because of the consequences of its truths.

About that, we can observe that for a century the world, thought as a dynamic totality of meanings, calls for a Metaphysics that responds to the restlessness brought about by quantum thinking (mechanics, physics and quantum biology) by the new discoveries of astronomy (it is enough to remember that until the beginning of the last century our universe was summed up the Milky Way, while, now we have the proof of the Einstein's thinking about the nature of gravity, I mean the very recent discovery of gravitational waves), new sciences such as cybernetics, and technologies that have allowed us to explore the nanological dimensions of reality.

We are faced with a paradox: it has never disdained itself so much from Philosophy as something non-essential and, nevertheless, we have never had so much need of

${ }^{2}$ Hegel, G. W. F. - Phänomenologie des Geistes, p.23.
Philosophy. The world needs Philosophy, but Philosophy lacks a new metaphysical basis and the construction of a metaphysics on a new basis requires the courage to dare, not inconsequently, not in edifying discourses, not in glimpses of genius, not in mediatic phrases, but in dialogue with the other knowledge and reality revealed by them, unveiled; a Metaphysics that is able to apprehend and expose in its logos the reality of nanotechnology laboratories, telescopes (such as Hubble and / or what is scheduled to be launched in 2018), social networks that rage on the internet, holographic and its fractals, the increasing complexity of the intra and inter-relations between us, in short, everything that constitutes our actual contemporary reality.

When Einstein summed up in his famous equation $\mathrm{E}=\mathrm{mc}^{2}$ the end of solidity and concreteness of matter, he implicitly made an unconscious appeal and not listened to by the philosophical community that matter could not remain the basis of Metaphysics as philosophical thought that ultimately aims to translate into concepts the new entanglement of meanings expressed by the world. What is surprising is the blindness of the great figures of the philosophy of the last century in seeing this demand, and what is most surprising is that we do not have to reinvent the wheel to propose a metaphysics on a non-material basis.

Husserl coined the phrase a change in the direction of the gaze, and certainly this phenomenological attitude may well be the starting point for this new Metaphysics, my proposal is: to change the direction of the gaze when revisiting Hegel, just as a Brazilian composer wrote in a popular song I like the Person in person, I call for us to put aside the Hegel of Marx, or the Marxists, or Kojève, or Fukuyama, or Popper and so many others, and perhaps we like Hegel more in the person, in the word that emerges of the text and insinuates meanings only caught between the lines of Hegelian discourse.

Well, Hegel in the person tells us: "Nothingness, while this immediate nothingness, equal to itself, is also, inversely, the same as being. The truth of being, as well as of nothing, is therefore the unity of the two: this unity is becoming. "3

Thus, the first manifestation of being or its phenomenalisation, or rather, constitutive of all being, itself still a non-being, is becoming-to-be. Becoming is being and nothingness as relation, and therefore in it the essence of all beings is to be related.

\footnotetext{
${ }^{3}$ Hegel, G. W. F. - Enzyklopädie der philosophischen Wissenschaften, I, p.188, §88.
} 
All that is, all that exists is a flow of relationships, this is the basis that is offered as the foundation of a new Metaphysics.

I will not here a systematic and thorough refutation of the criticism of Metaphysics, published in the near past century, so plan to spend a longer study and possibly receive the book format, although always ask me if it is worth dealing with this issue often, since the substance of my criticism is directed to the general principle of criticism, that is, that criticism has taken traditional metaphysics as the only possible one; just as critics of instrumental reason have taken it for all reason, and on the basis of this misconception they have denied the possibility that reason governs the world, it is the old logical mistake of taking the part for the whole.

According to my understanding, which may equally be mistaken, Metaphysics, as the tradition bequeathed to us, was born with Thales of Miletus.

Philosophy $\rightarrow$ Cosmology $\rightarrow$ Ontology

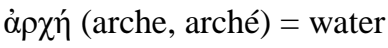

What is the necessity that led Tales to formulate a knowledge that will later be called Philosophy and within this knowing what is called Metaphysical?

Clarify immediately that I am well aware that the term Metaphysics comes only part of the philosophical vocabulary and later for even Aristotle so called his work on being, which we know today titled Metaphysics, without him of this title, it is clear that no one is ignorant of the picturesque origin of the title of the work of Aristotle, etc. and such. I am referring to what is understood by Metaphysics.

Tales needed to find a knowledge that was not mere doxa (opinion) and that had no origin in the gods, because, in his time Miletus, like all Ionia, was under Athenian rule, it was colony of Athens, this relationship of domination did not was maintained by force of arms, but was justified by the presence of the gods; that the colonies of Athens were made up of Athenians, who, having no means of survival in Athens, were shipped on ships, usually by their parents, with provisions and with the guidance that wherever they found favorable land there, they would settle down, Athens, not only to pay off the debt owed to the journey, but above all to ensure the worship of the gods by those who stayed in Athens, this strong connection of mediation to the creator gods of the cosmos and all that there is it was in him that he maintained domination.

Not without reason, that the first colonies to be liberated were those of the Ionia, after the contribution of Thales, who for centuries anticipates in practice what Lenin once will say: there is no revolution without a theory of revolution.

When Tales manages to demonstrate the validity of the knowledge acquired by him in his travels and announces that arche, the principle in the double sense like the begin and the essential substance of all things, is water, evident not the water that is drunk or used in the daily life, but water as the principle of moisture present in all things, and that therefore it was not the gods who created the cosmos but this material principle, is the revolutionary thought that disavows the Athenian domination.

It is not difficult to see the necessity of a material arche, with appeal to the senses of the common man, in fact, the argument was strong: water as we know it and that derives immediately from the principle of humidity, is the most common element, present in all that exists, allowing until Tales proposes a theory of evolution, according to which the most evolved things are those that contain more water in its composition.

The immediate successor of Tales, his disciple, Anaximander, innovating the relationship master-disciple, will tell us that archeit can't be water, nor any other known element, but something that is not allowed to determine the apex, but in all case it is a material principle. And all the tradition that follows will propose variations of the matter of arké, but not that it is a material principle. Even the being of Parmenides will be described by him as a perfect sphere out of which there is non-being.

In fact, from the proposition of this material base, whether as an atom, as first formless matter, and so on, we have come to the contemporary critique that says: in metaphysics seeking to be found the being and satisfied with it. But being is not an entity, the question is that questions the being is badly formulated, nobody can ask what being is, but what one means when one says Being. However, this same criticism asserts that being is said, it is revealed, language is the home of being, in that dwelling dwells the man and in it exercises the custody of the being.

I always have the impression that here is also spoken of a being! A special being, but still a material entity, perhaps for this reason Heidegger himself will say later that in Being and Time he thought of being from the threedimensionality of space and set out to write Time and Being where he intended, according to him, to make the correction, a pity that this text has been unfinished.

The ontological difference between being and entity, proper of this dualistic style of thinking that still seems to confuse Understanding and Reason, is basically a representation of the outer difference, which thinks the finite as opposed to the infinite and not as the moment of this. 
Allow me to insist: the beginning of the 20th century was marked by great scientific discoveries - those of physics (relativistic, quantum), astronomy (that the universe is larger than our galaxy, black holes); to these discoveries followed so many that came through cybernetics, systems theory, information theory, new biology, light chemistry, and so on. All this, as a whole, served to demand a new understanding of the world, of the universe and of humanity itself.

Nonetheless, scientific and technological development at the same time reinforced positivist domination, while a complex, work-oriented, capital-driven society reinforced the hegemony of the current economic system under the mantle of formal thought. And at the bottom of all this is a material-based metaphysics, abandoned by philosophers at the hands of physicists and astronomers, utterly incapable of responding to the demands of a time when $E=m c^{2}$ is a commonplace, where the existence of stars billions of years -light from here is newspaper news, in which diseases affecting humanity are no longer attributed to divine punishment or mysteries, but the presence of viruses and bacteria identified in laboratories, at a time when the passage of neutrinos across the planet is detected and the speed of light remains the absolute threshold only because overcoming this truth would undermine the foundations of science.

In short, the emergence of feminist movements, of equal rights movements among human races, of networked social organizations, of instant communications between physically distant places, of volatile financial capital, that is, of the new figures of the spirit, constitute a new a totality that also requires new conceptual tools, but undoubtedly the first requirement is a new metaphysics, not the so often announced end of metaphysics, but the realization that the change of metaphysical basis will lead to another way of thinking, which may come to meet Einstein's diagnosis, which can be summarized in the sentence: the thought that has led us here is unable to get us out of here.

Hence, in the Phenomenology of the Spirit, Hegel begins with the immediacy of the self-consciousness, at the beginning of the Science of Logic immediacy is the being which is nothingness, whose difference between one and another lies only in the intentionality of the cognoscenti subject. The question asked, a little more than a century after Hegel - why being and not nothingness? It thus becomes inessential or reveals an ignorance of the Hegelian text or simply a refusal to accept the truth of the text.

In any case, I return to Hegel in person and encounter:
What matters is precisely consciousness about these beginnings, namely, that they are nothing other than these empty abstractions, and that each of the two [being and nothing] is as empty as the other. The impulse to find in the being, or both, a firm meaning is that very necessity that carries forth being and nothingness, and gives them a true meaning, that is, concrete. (...) Reflection, which finds for them deeper determinations, is logical thinking, by means of which such determinations are produced, not in a contingent but necessary way. Each subsequent signification they receive must therefore be seen as a more precise determination and a truer definition of the absolute. $^{4}$

Thus the dialectic of the concept which allows us to apprehend the being has as a requirement for its demonstration conceptual, the phenomenology of the selfconsciousness in the becoming of itself as spirit which is known as spirit (which corresponds to the path of selfconsciousness in Hegel's Phenomenology), and has as its starting point the immediate and empty abstractions of the being and from nothing which is also the contradiction that drives the dialectic of inner difference in its initial effectiveness, its manifestation in determinations. Since, I repeat, "nothingness, while this immediate nothingness, equal to itself, is also, inversely, the same as being. The truth of being, as well as of nothingness, is therefore the unity of the two: this unity is becoming" .

Therefore, if substance is essentially subject, as Hegel presents us from the Preface to his Phenomenology, and this subject becomes effective as self-consciousness, which at the end of the process in which its becoming culminates is spirit, whose simplest manifestation is says I, it is worth remembering that from the Hegelian perspective the $\mathrm{I}$ is the content of the relation, the relate and the self-relate with own self. ("Ich ist der Inhalt der Beziehung und das Beziehen selbst"6). This means that we must think of actual or phenomenological reality in terms of quantum collapse of polysemic totalities of relations.

Indeed, when we stand within the framework of the Hegelian system, the real is opened before us as the field of the possible, of the infinite possibilities of this real to be effective; the very point from which, far from seeking solutions to the contradictions, one seeks to apprehend them in the very dynamics of their movement, in the incessant vortex of their multifaceted manifestations, in the plethora of a thought of the Absolute which is the very

\footnotetext{
${ }^{4}$ Hegel, G. W. F. - Op. cit. $§ 87$, p.179.

${ }^{5}$ Hegel, G. W. F. - Id. §88, p.180

${ }^{6}$ Hegel, G. W. F. - Phänomenologie des Geistes, pp.137,138.
} 
being and whose manifestation more meaningful is the Concept.

In effect, this dialectical movement will reveal to us that:

Only the Concept can apprehend all the differences including the differences of its Other - in its identity, while it is the universal that, in an immanent way, unfolds in the particularities that, denial of the universal for itself, are therefore the affirmation of and therefore only denied for himself in them, he met with himself in a concrete or systematic way. ${ }^{7}$

The Hegel System is the presentation of the Absolute, it has the Absolute as its objectand, simultaneously, its subject, its substance. And it would be lacking in consistency if there were something outside the Absolute, that is why "the life of God and divine knowledge may well be expressed as a play of love with oneself." 8

In this System we - finite spirits - are not only part of this game, but we are its protagonists, we are the effective through which the Absolute mediates, manifests itself, knows itself and says of itself.

In this sense, the concept, as the fullest expression of what the absolute says of itself, must be all-embracing, the truth of the true which is the whole. That is why phenomenology is a necessary moment, as long as we understand the necessity as a posteriori, Phenomenology of Spirit as the ladder to which the individual has the right to rise from ignorance to absolute knowledge, precedes science, but is already itself science and unfolds in Logic, in the Philosophy of Nature and in the Philosophy of the Spirit, moments of the Knowing that is Being in its effectiveness.

The Hegelian warning that absolute knowledge is a sine qua non for doing science has often been neglected; readers of the Phenomenology should therefore be warned that this book was not written to be simply read, but to be rewritten in each reading, to be experienced, enjoyed, become part of the spirit of the reader in the final revelation in which the reader reveals himself even as the spirit that is known as spirit.

Nothing is easier to understand what it is to be a spirit known as a spirit, nothing more difficult to perceive, than to be perceived, above all, after the twentieth century and the hegemonic dominance exercised in it by positivism, formalism and metaphysics of a material basis, which, despite having been surpassed by the same knowledge that it produced and paradoxically dethroned the substantiality of matter, remains the official thought of our time, the very

${ }^{7}$ Bourgeois, Bernard - In Présentation de l'Encyclopédie des Sciences Philosophiques, I. La Science de la Logique, p. 14.

${ }^{8}$ Hegel, G. W. F. - Phänomenologie des Geistes, p.24. measure in which it serves the dominant power, is affirmed as a single thought, in terms of validity and interpretation of our reality. So that Hegel's voice remains divergent, and those who dare to claim this voice to be heard are the insurgents (divergent and insurgent terms used here in an allusion to the recent cinematic language, in a film that not coincidentally has a heroine as its character central), because they oppose the Hegelian system to the belief system, which now has in the ideology of the politically correct its best ally.

And if you know yourself as spirit is the condition, how is this possible in a context in which the brain is studied to explain the mind as its byproduct or, what is the same in Cartesian language, in a world where the extended thing (res extensa) is cause of the thinking thing (res cogitans)? The prevailing belief system makes people believe that they have a soul as a good or product that one possesses, causes them to forget or do not know that, I quote Hegel again in the person, "the spirit differs from the soul - that is, so to speak, the term mediator between corporality and spirit, or the bond between the two. Spirit, as soul, is immersed in corporeality, and the soul is the vital principle of the body". 9

It is urgent, therefore, to correct the famous and ill-fated Hegelian inversion, since it is not the phenomenon that produces the consciousness, much less the consciousness that produces the phenomenon, but the consciousness is the relation that is established in the act of producing the knowledge of the phenomenon, be it internal or external to Self-consciousness. For me self-consciousness is not to look at one's own navel in a mirror, but, self-consciousness is to look at oneself in the other, recognizing the other as another of oneself in its difference and uniqueness, this understanding is a requirement of Hegelian thinking. This then sets out the reason why the Phenomenology is understood as the first moment of the dialectic that allows us to apprehend the Being.

The gross, shallow irony of knowledge is pleased to jokingly repeat that Hegel thought what God thought before thinking, in fact, a little knowledge is enough to dispel the supposed motive of laughter implicit in this phrase.

Again, the virtue of coherence made Hegel state, among other assertions, that "what is rational is effective and what is effective is rational" 10 , or, it means to say that there is no effective reality that cannot be grasped by reason and we

\footnotetext{
${ }^{9}$ Hegel, G. W. F. Enzyklopädie der philosophischen

Wissenschaften, I, p.100, § 34,Zusatz.

${ }^{10}$ Hegel, G. W. F. - Grundlinien der Philosophie des Rechts, p.24.
} 
know that everything what is rational is only because it can be the object of the logos, of reason and be placed in the philosophical discourse, in the speech that must be kept from being edifying to being full of meaning.

Hegel, therefore, could not admit in his system any presuppositions, no truths which could not be rationally demonstrated, no apodictic evidence which dispensed with its rational demonstration. Thus, in the Phenomenology where it presents a theory of knowledge in its immanent development, it begins in the Sensitive Certainty, at the moment when the consciousness-of-itself, devoid of all knowledge, believes to have the richest knowledge by not abstracting from the object of its knowledge, and to discover miseryof this knowledge, instigated by the philosopher who provokes it, puts itself in the movement that will ultimately lead it to absolute knowledge, in the play of mediations permeated by figures and experiential moments.

In fact, "being in becoming as one with nothingness, and thus nothingness, as one with being, are only evanescent: becoming, by its contradiction within itself, collapses in the unit in which the two are superseded; its result is therefore the being-there." 11 Being-there is the override of being-as-being as relation of being and of nothing, that as something, being determined, is the contradiction of having its negation in itself, since omnisdeterminatioestnegatio, that truth or unveiling which, according to Hegel, would be enough to give Spinoza a place of prominence in the History of Philosophy.

However, this Metaphysics cannot stop at its beginnings, but must unfold, develop, seek its effectiveness, but now the process is concentrated in determinations, first only in thinking, in the logical and ontological dimension, until it is moved by the internal dynamics of its relations to beingthere while the truth of being-to-be is to be extruded, to deepen, Hegel tells us:

Such a deepening of the becoming-in-itself we have, for example, in life. Life is a coming-to-be, but its concept does not end there. In a higher form we find still the becoming in the spirit. This is also a coming-to-be, but a coming-to-be more intense, richer than simply becoming logical. The moments, of which the spirit is unity, are not mere abstracts of being and nothingness, but the system of the logical idea and of nature. ${ }^{12}$

Nevertheless, the foundation, the being, the web of relations that are in the process of implies a Metaphysics capable of permeating and integrating Phenomenology,

\footnotetext{
${ }^{11}$ Hegel, G. W. F. - Enzyklopädie der philosophischen

Wissenschaften, I, p. 193, § 89.

${ }^{12}$ Hegel, G. W. F. - Id., pp.188-195, §§ 88-89.
}

Logic, Nature and Spirit as constitutive terms of the dialectic of its consummation, requires that these terms be understood here only in the sense in which the terms of a dialectical syllogism are given, that is, in the sense in which they alternate in the logical functions, but never in the sense of a temporal linearity, since the essential category of the Hegelian dialectic is the simultaneity, in its exposition the successivity is only a demand of the language.

At this point, it is worth quoting Hegel again in person:

Knowing, already contained in the simple logical idea, is only the concept, thought by us, of knowing; not to know it for itself, nor the effective spirit, but simply its possibility. The effective spirit, which is our object only in the science of the spirit, has the outer nature by its closest presupposition, as has the logical idea by its first presupposition. Therefore, as its final result, the philosophy of nature - and logic, immediately - must have proof of the necessity of the concept of the spirit. (...) This truth of necessity is, therefore, freedom; and the truth of substance is the concept. ${ }^{13}$

We have just left a century in which we had a profusion of commentators and repeaters of the preceding philosophical thought, now we need producers, inventors, true philosophers who will meet the imperative need to translate our time in Concept, the lack of Philosophy is felt in the frivolity, the boredom and the impatience that rage in the educated academy of our time.

Let me return to something I have already expressed, without any arrogance, without grandiose things, but only by returning to myself in a work published in part time:

The material base which gives support to the Metaphysics that the tradition bequeathed to us, was disintegrated in the air, the physical sciences no longer have, properly, of something physical in the strict sense; It is even said that physicists, as they penetrated the gaze of science into the supposed atom, encountered a fluidity and uncertainty never imagined; there is not in this interior something that can even properly be called a particle, not even the socalled 'particle of God', nothing but the unity resulting from the relations between the strong, weak, electromagnetism and gravity forces; in fact, what they have found are connective and connected relationships, which form compact units and constitute the ultimate basis upon which our 'physical' reality rests.

We could even say that the object of knowledge of the physical sciences is now the Concept in its evanescent manifestation and, therefore, perhaps the crisis of

\footnotetext{
${ }^{13}$ Hegel, G. W. F. - Id., pp.15, 287, $§ \S 381,158$ respectively.
} 
paradigms is a symptom of the lack of Philosophy, more specifically, of Philosophy that implies a resizing of knowledge, from a possibly relational-based Metaphysics.

In everything the advent of a new figuration is revealed, the evanescence imposed by the new figures of the spirit, which is translated into the quantum of information (knowledge) produced as in the speed with which this information reveals its insufficiency to be suppressed almost immediately to acceptance as truth . In everything it is manifested to contemporary man, the indication that his world has a new configuration and that he himself, as creator-creature of this world, needs to abandon the outdated presuppositions of positivist scientism to launch himself to the challenge of understanding himself even as a finite spirit and its actual spiritual reality, from anentity (Seiend, Dasein) that is full to Being and that, in its identity with knowledge, is a knowing that is to Being. For now, this is still a goal, we know that a goal exists to be a target, but when the poet says goal may be saying the unattainable and when the philosopher says goal may be wanting to mean something that always exceeds the finite conditions of its accomplishment . Thus, as Schiller would say, quoted by Hegel as a corollary to his Phenomenology, only 'from the glass of that kingdom of spirits does his infinity foam to himself.' [Schiller].

And there is an invitation to the boldness that we can again give voice to Philosophy, based on a relational-based metaphysics that, beyond from the feminine and the masculine, preserves identity in the difference, I know that a truth usually takes a long time to be understood, accepted, assimilated and lived, it is enough to remember that we still use expressions such as "the sunset", even knowing for centuries that the sun does not set; for this reason I appeal to stop reducing ourselves to matter, so that we rethink common expressions that reinforce this thought, such as; 'Broken heart', 'fragmented subject', 'uncentred person' and gave rise to a thought that opens to the infinite dimensions that constitute reality and permeate and are part of the spirit that we are in this human experience that we now experience; feminine theology has drawn attention to the realization that God can also be Goddess, because in Him this determination is inessential, although few dare to say "Our Mother who are in the heaven...".

I believe that the time has come to suppress all that separates us into determinations that only distinguish us and contribute to each affirming one's self in the difference of the other. I cry out for female categories, elements and concepts present in this relational-based Metaphysics, I cry out for a female voice that proclaims them, I cry because I believe that the deepest desire we experience, the one that is constitutive even of our ontological root and incompleteness, is desire of being itself that is primarily consumed when I suppose, I desire the other in the desire of the other's desire, in the dialectic of recognition that allows us to glimpse the image and likeness of the spiritual divinity of which we are moment and figure.

\section{REFERENCES}

[1] Bourgeois, B. - In Présentation de l'Encyclopédie des Sciences Philosophiques, I. La Science de la Logique. Paris. 3 ed. LibrairiePhilosophique J. Vrin, 1986.

[2] Hegel, G. W. F. - Enzyklopädie der philosophischen Wissenschaften. Werke in 20 Bänden. Frankfurt am Main. 3 ed. Suhrkamp, 1991.

[3] Hegel, G. W. F. - Phänomenologie des Geistes. Werke in 20 Bänden. Frankfurt am Main. 3 ed. Suhrkamp, 1991.

[4] Hegel, G. W. F. - Grundlinien der Philosophie des Rechts. Werke in 20 Bänden. Frankfurt am Main. 3 ed. Suhrkamp, 1991.

[5] Moraes, Alfredo O. - A Metafísica do Conceito: Sobre o problema do Conhecimento de Deus na Enciclopédia das Ciências Filosóficas de Hegel. Porto Alegre. EDIPUCRS, 2003.

[6] MORAES, Alfredo de Oliveira. Uma metafísica para além do feminino e do masculino. Kalagatos, Fortaleza, Vol.15, N.1, 2018, p. 203-217. 